\title{
ISOLATION OF CELLULOLYTIC BACTERIAL STRAINS FROM RANGIFER TARANDUS RUMEN MICROFLORA
}

\author{
Andrey Dubrovin ${ }^{1}$, Timur Dunyashev ${ }^{1}$, Larisa Ilina ${ }^{1}$, Valentina Filippova ${ }^{1}$, Kasim Laishev $^{2}$ \\ ${ }^{1}$ BIOTROF+ LTD, Russia \\ ${ }^{2}$ North-West Center for Interdisciplinary Research on Food Security Problems, Russia \\ dubrowin.a.v@yandex.ru
}

\begin{abstract}
The feature of the microorganisms of rumen microbiocenosis is the ability to form a number of digestive enzymes, including cellulases, which allows ruminants use the energy of feeds rich in fiber. Microorganisms that are promising as a source of cellulases, biodestructors of toxins having antagonistic properties against pathogens for creating probiotic feed additives, both for reindeer and for other livestock, were isolated from the reindeer rumen. The aim of the study was to create a collection of microorganisms that are promising for creating a biopreparation.

As a result, collections of 63 associations of microorganisms decomposing cellulose and carboxymethylcellulose were created, their morphology and cultural properties were described. It was found that the amount of cellulose degradation was $44-62 \%$ in the 4 most active isolates (No 14, 15, 21 and 26). The obtained data allowed to make a conclusion about the ability of bacterial strains isolated from the rumen to synthesize cellulolytic enzymes carrying out cellulose biodegradation, which allows them to gain a competitive advantage in the rumen of the reindeer diets with an abundance of cellulose. Isolates No 14 and 15 showed high antagonistic activity to Fusarium sporotrichioides, and isolate No 15 and 16 showed high antagonistic activity to Fusarium oxysporum. Isolate No 15 showed a wider antifungal activity compared to other isolates. Among all isolated strains, this bacterial isolate is represented as having a large spectrum of activities, including both high cellulolytic and high antifingal activity.
\end{abstract}

Key words: cellulolytic bacteria, Rangifer tarandus, rumen bacterial community, Russian Arctic.

\section{Introduction}

The absorption of plant feed in reindeer (Rangifer tarandus) occurs, as in other ruminants, due to enzymes produced by rumen symbiotic microorganisms. The rumen of reindeer is known to be inhabited by bacteria, archaea, fungi, and protozoa. Most of the bacterial rumen symbionts assigned to the Firmicutes (Mathiesen et al., 2005; Sundset et al., 2009).

Reindeer is one of the special animals that live in conditions of poor diet, a significant part of which is lichens. The bacteria of the phylum Bacteroidetes, Actinobacteria and Proteobacteria were found in the Rangifer tarandus rumen community in a lesser extent. In a minor amount representatives of phylum Tenericutes and Fusobacteria, Acidobacteria, Cyanobacteria were found in the reindeer's rumen (Ilina et al., 2018). In the summer-autumn period, the basis of the reindeer diet is plants - cereals, sedges, willow leaves, dwarf birch trees and the proportion of lichens does not exceed $15 \%$. In the winter-spring period, the share of lichens in the diet of reindeer increases to $70 \%$, and the remaining $30 \%$ are residues of green plants, mosses, and various impurities (Orpin, 1985). Such a diet is dangerous because of the high amounts of usnic acid found in lichens, which is toxic to animals (Guo et al., 2008). In addition, lichens are producers of other harmful metabolites, in particular, mycotoxins (Tolpysheva, 2014).Thus, a community of microorganisms adapted to high quantities of lichens metabolites and having celulolytic properties should have been formed in the rumen of a reindeer. That is why the isolation of microorganisms from the rumen of reindeer is promising for the search for microorganisms with high cellulolytic activity and able to become part of probiotic.

Probiotics are living microorganisms whose use has a positive effect on many functions of the body (Hadieva et al., 2018). One of the important properties required for probiotics in ruminants is the decomposition of cellulose; therefore, the isolation of highly active bacterial strains with cellulolytic activity from reindeer's rumen is promising for creating biopreparations for cattle. The aim of the study was to create a collection of microorganisms that are promising for creating a biopreparation.

\section{Materials and Methods}

Four samples of fresh reindeer's rumen liquid from Yamalo-Nenets (a healthy calf and an adult animal) and Nenets Autonomous districts (samples from a healthy adult male and female) were received in the laboratory. Samples of rumen liquid $(1 \mathrm{ml})$ each were sown on liquid nutrient medium $(0.5$ 1 meat peptone broth, 0.51 distilled water, $0.5 \%$ chalk, filter paper (2-3 strips)) in a $10 \mathrm{ml}$ and cultured at $37^{\circ} \mathrm{C}$ under aerobic conditions. Not later than 5 days, decomposition of the filter paper was observed (Tepper, Shilnikova, \& Pereverzeva, 1993). Cellulose-decomposing associations were determined by the presence of lysis zones of filter paper at the end of the experiment. Selected associations were cultivated on carboxymethylcellulose medium $\left(5 \mathrm{~g} \mathrm{l}^{-1}\right.$ carboxymethylcellulose, $0.1 \mathrm{~g} \mathrm{l}^{-1}$ malt extract, $0.04 \mathrm{~g} \mathrm{l}^{-1}$ yeast extract and $2 \mathrm{~g} \mathrm{l}^{-1} \mathrm{CaCO}_{3}$ (Ngangi et al., 2013)) for the determination of cellulose degrading bacteria in associations. 
A total of 63 isolates decomposed carboxymethylcellulose (determined by the presence of lysis zones carboxymethylcellulose) in aerobic conditions were isolated. Then their ability to decompose cellulose (filter paper) was evaluated.

The method for evaluation cellulolytic activity of selected isolates according to Henderson, Horvat and Block in the Churlis modification (Churlis, 1958; Tarakanov, 2006) is based on determining the difference in cellulose weight (filter paper) before and after its incubation with the liquid culture of microorganisms in vitro. The liquid culture of the isolated associations $(1 \mathrm{ml})$ in duplicate was introduced in $9 \mathrm{ml}$ per tube with a filter, dried to constant weight at the temperature of $104-106{ }^{\circ} \mathrm{C}$ and medium $\left(\mathrm{NaH}_{2} \mathrm{PO}_{4}-2041.6 \mathrm{mg} \mathrm{l}^{-1}\right.$, $\mathrm{NaHCO}_{3}-2041.6 \mathrm{mg} \mathrm{l}^{-1}, \mathrm{KCl}-262.4 \mathrm{mg} \mathrm{l}^{-1}, \mathrm{KJ}-$ $28.03 \mathrm{mg} \mathrm{l}^{-1}, \mathrm{NaCl}-262.4 \mathrm{mg} \mathrm{l}^{-1}, \mathrm{MgSO}_{4}-8.5 \mathrm{mg} \mathrm{l}^{-1}$, $\mathrm{FeSO}_{4} * 7 \mathrm{H}_{2} \mathrm{O}-31.2 \mathrm{mg} \mathrm{l}^{-1}, \mathrm{MnSO}_{4}-15.6 \mathrm{mg} \mathrm{l}^{-1}$, $\mathrm{CuSO}_{4} * 5 \mathrm{H}_{2} \mathrm{O}-1.6 \mathrm{mg} \mathrm{l}^{-1}, \mathrm{ZnSO}_{4} * 7 \mathrm{H}_{2} \mathrm{O}-0.47 \mathrm{mg} \mathrm{l}^{-1}$, $\mathrm{CoSO}_{4}-0.7 \mathrm{mg} \mathrm{l}^{-1}, \mathrm{Na}_{2} \mathrm{P}_{4} \mathrm{O}_{7} * 10 \mathrm{H}_{2} \mathrm{O}-0.07 \mathrm{mg} \mathrm{l}^{-1}$, $\mathrm{CrCl}_{2} * 5 \mathrm{H}_{2} \mathrm{O}-0.16 \mathrm{mg} \mathrm{l}^{-1}, \mathrm{~K}_{2} \mathrm{CrO}_{4}-0.08 \mathrm{mg} \mathrm{l}^{-1}$, $\mathrm{NaAsO}_{3}-0.13 \mathrm{mg} \mathrm{l}^{-1}$, glucose $500 \mathrm{mg} \mathrm{l}^{-1}$, urea $840 \mathrm{mg} \mathrm{l}^{-1}$, distilled water $-1 \mathrm{l}$ ), in duplicate. It was kept in a thermostat for up to 2 weeks at the temperature of $37^{\circ} \mathrm{C}$. Then, the filter was removed, washed and dried to constant weight at the temperature of $104-106{ }^{\circ} \mathrm{C}$. Filters were weighed and the amount of decomposed cellulose in the sample was calculated (Tepper, Shilnikova, \& Pereverzeva, 1993).

Themost active cellulolytic isolates were tested for antagonistic activity against Escherichia coli and the fungi Fusarium oxysporum and Fusarium oxydans.

The culture of antagonist strain was mixed with a $20 \%$ agarose nutrient medium ( $1 \mathrm{ml}$ of culture per $200 \mathrm{ml}$ of medium) and evenly poured into Petri dishes, after solidification of the medium, wells were made into it, into which $200 \mu$ l of culture of the isolates were poured. Petri dishes were cultivated in a thermostat at $37{ }^{\circ} \mathrm{C}$ for E. coli, at $30{ }^{\circ} \mathrm{C}$ for Fusarium sp. during the day in three replications for each strain. Antagonistic activity was determined by the presence/ absence of the growth zone / growth retardation in the antagonist strain. The zone was measured in order to determine the degree of activity of the strain.

\section{Results and Discussion}

All selected isolates had a similar morphology: whitish colonies with a diameter of $0.1-1 \mathrm{~mm}$ on the medium with carboxymethylcellulose. Two associations (No 7 and 46) had a yellow color. Microscopy of the sample showed the presence of several cell types in the samples, which were similar between the samples: small cocci (diplococci, streptococci), small rods, large clostridial rods. A total of 63 isolates decomposed cellulose in aerobic conditions were isolate. Then their ability to decompose cellulose (filter paper) was evaluated. It was found that 10 of 63 isolates had the high ability to degrade filter paper. The results are presented in Table 1. The isolates No 14, 15, 21, and 26 turned out to be the most active, decomposing $44-62 \%$ of the original cellulose according to Henderson, Horvat and Block method in the Churlis modification.

Table 1

Determination of cellulolytic activity of isolated isolates by the method of Henderson, Horvath and Blok in the modification of Churlis

\begin{tabular}{|c|c|c|c|}
\hline \multirow{2}{*}{ Isolate No. } & \multicolumn{2}{|c|}{ Cellulose loss } & \multirow{2}{*}{$\begin{array}{c}\text { The amount of } \\
\text { decomposed cellulose, } \\
\%\end{array}$} \\
\hline & $\mathrm{mg}$ & $\%$ & \\
\hline \multirow{2}{*}{7} & 80 & 4.0 & \multirow{2}{*}{4.0} \\
\hline & 80 & 4.0 & \\
\hline \multirow{2}{*}{14} & 880 & 44.0 & \multirow{2}{*}{44.0} \\
\hline & 880 & 44.0 & \\
\hline \multirow{2}{*}{15} & 950 & 47.5 & \multirow{2}{*}{47.8} \\
\hline & 960 & 48.0 & \\
\hline \multirow{2}{*}{21} & 1100 & 55.0 & \multirow{2}{*}{56.8} \\
\hline & 1170 & 58.5 & \\
\hline \multirow{2}{*}{24} & 360 & 18.0 & \multirow{2}{*}{17.8} \\
\hline & 350 & 17.5 & \\
\hline \multirow{2}{*}{26} & 1240 & 62.0 & \multirow{2}{*}{62.0} \\
\hline & 1240 & 62.0 & \\
\hline \multirow{2}{*}{37} & 190 & 10.0 & \multirow{2}{*}{9.5} \\
\hline & 180 & 9.0 & \\
\hline \multirow{2}{*}{46} & 120 & 6.0 & \multirow{2}{*}{6.0} \\
\hline & 110 & 6.0 & \\
\hline \multirow{2}{*}{51} & 210 & 11.0 & \multirow{2}{*}{10.0} \\
\hline & 180 & 9.0 & \\
\hline \multirow{2}{*}{58} & 540 & 27.0 & \multirow{2}{*}{25.5} \\
\hline & 480 & 24.0 & \\
\hline \multirow{2}{*}{ Control $^{*}$} & 0 & 0 & \multirow{2}{*}{0} \\
\hline & 0 & 0 & \\
\hline
\end{tabular}

* control - without inoculum

The obtained data allowed to make a conclusion about the ability of bacterial strains isolated from the rumen to synthesize cellulolytic enzymes carrying out cellulose biodegradation, which probably allows them to gain a competitive advantage in the rumen of the reindeer consuming diets with an abundance of fiber. The most active cellulolytic isolates No 14, 15, $21 \& 26$ were tested for antagonistic activity against Escherichia coli and the mycotoxin-producing fungi Fusarium oxysporum and Fusarium sporotrichioides. The results are presented in Table 2 and Figure 1. 
Determination of antagonistic activity in isolated isolates by the method of 'wells', mm

\begin{tabular}{|c|c|c|c|}
\hline Isolate No. & Escherichia coli & Fusarium sporotrichioides & Fusarium oxysporum \\
\hline 14 & $1 \pm 0.04$ & $40 \pm 2.7$ & $10 \pm 0.8$ \\
\hline 15 & $2 \pm 0.09$ & $50 \pm 3.0$ & $50 \pm 3.4$ \\
\hline 21 & $-*$ & - & - \\
\hline 26 & - & - & $50 \pm 2.4$ \\
\hline
\end{tabular}

* antagonism was absent.

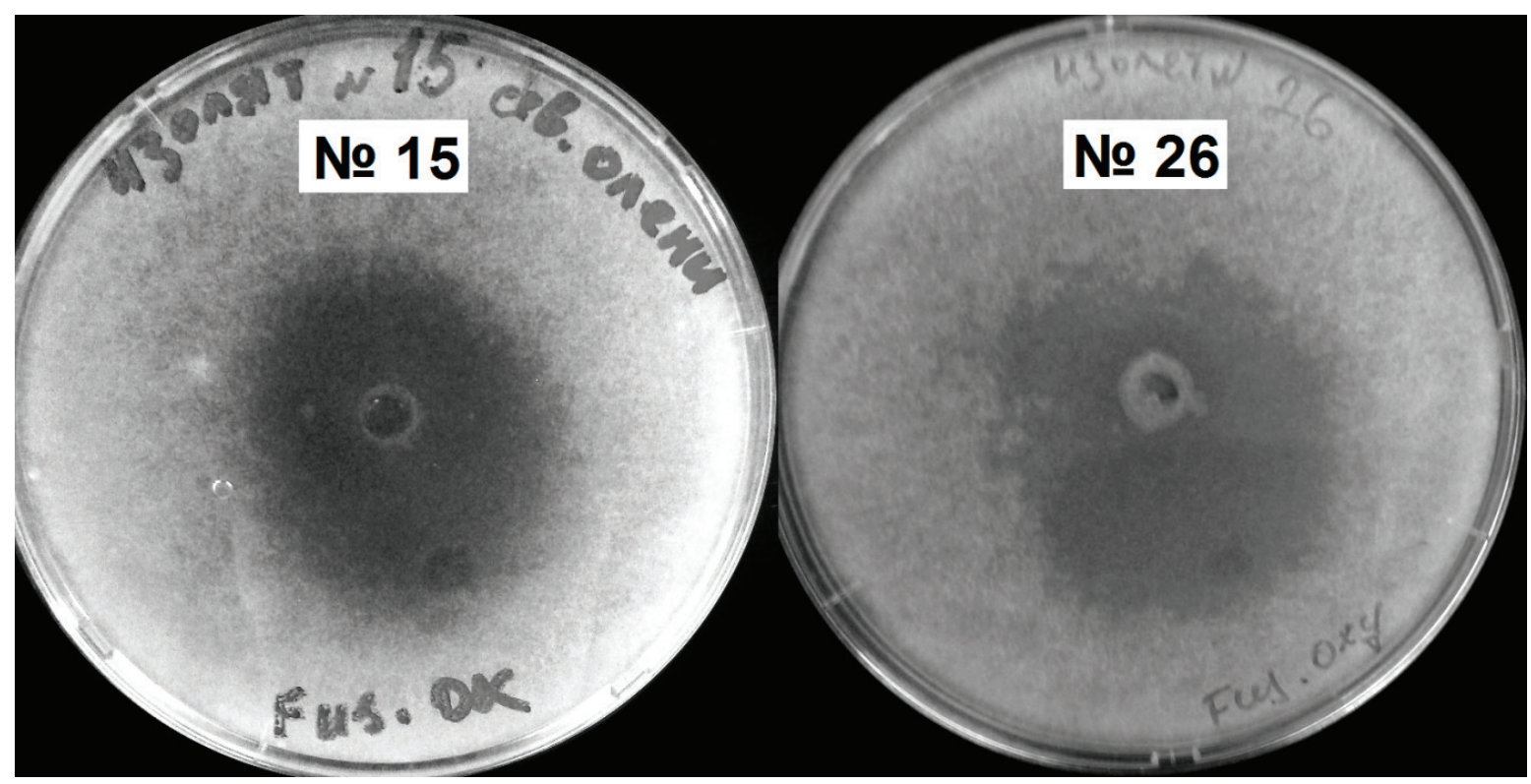

Figure 1. Antagonistic activity of strains isolated from the rumen of reindeer No 15 and No 26 against Fusarium oxysporum.

The antagonistic activity of bacterial isolates in our experiments was different. It was manifested differently in relation to micromycetes and bacteria: there was practically no antagonism towards Escherichia coli, whereas isolates No 15 and 26 showed high antagonism to Fusarium oxysporum (50 \pm 3.4 and $50 \pm 2.4 \mathrm{~mm}$, respectively), and isolates No 14 and 15 showed high antagonism to Fusarium sporotrichioides $(40 \pm 2.7$ and $50 \pm 3.0$ $\mathrm{mm}$, respectively). The obtained results confirm the presence of antimicrobial substances in the culture fluids. Isolate No 15 showed a wider antifungal activity compared to other isolates. This is due to the different spectrum of antimicrobial and antifungal substances produced by these bacteria. Among all isolated strains, this bacterial isolate is represented as having a large spectrum of activities, including both high cellulolytic and high antifingal activity.

\section{Conclusions}

The obtained data allowed us to make a conclusion about the ability of bacterial strains isolated from the rumen to synthesize cellulolytic enzymes carrying out cellulose biodegradation, which allows them to gain a competitive advantage in the rumen of the reindeer diets with an abundance of cellulose. The presence of antimicrobial substances produced by cellulolytic bacteria also gives them an advantage among other microorganisms in the reindeer rumen. Among the 4 most active cellulose-decomposing bacterial isolates, strain No 15 was the most effective. This strain had a high cellulolytic and antagonistic activity against two species of mycotoxin-producing fungi of the genus Fusarium.

\section{Acknowledgements}

The research was carried out with the support of the grant of the Russian Science Foundation (RSCF) No 17-76-20026 'Microbiocenosis of the Rangifer tarandus rumen of the Arctic regions of Russia as a fundamental basis for obtaining promising biotechnologies for farm animals'. 


\section{References}

1. Churlis, T.K. (1958). About the method of determining the activity of cellulose-splitting microflora of the reticulorumen of the cattle. Feeding of farm animals. M.: Selkhozizdat.

2. Guo, X., Jie, X.L., Hu, H.F., Liu, S.L., \& Liu, F. (2008). Analysis on applied effects of different forage combinations used in rabbit production. Prataculture \& Animal Husbandry. 11, 12-15.

3. Hadieva, G.F., Lutfullin, M.T., Mochalova, N.K., Lenina, O.A., Sharipova, M.R., \& Mardanova, A.M. (2008). Novel strains of Bacillus subtilis as promising probiotics. Microbiology. 87 (4), 356-365. DOI: 10.1134/S0026365618040110.

4. Ilina, L.A., Laishev, K.A., Yıldırım, E.A., Filippova, V.A., Dunyashev, T.P., Dubrovin, A.V., Nikonov, I.N., Novikova, N.I., \& Laptev, Yu, G. (2018). Comparative analysis of rumen bacterial community of young and adult Rangifer tarandus reindeers from arctic regions of Russia in the summer-autumn period. Agricultural Biology. 53 (2), 355-363. DOI: 10.15389/agrobiology.2018.2.355eng.

5. Mathiesen, S.D., Mackie R.I., Aschfalk, A., Ringo, E., \& Sundset, M.A. (2005). Microbial ecology of the gastrointestinal tract in reindeer - changes through season. Biology of the Growing Animals. 3, 73-100. Elsevier Press, Oxford.

6. Ngangi, J., Pelealu, J., Warouw, J., \& Mandey, L. (2013). Isolation and activity of cellulolytic bacteria isolated from hindgun of Odontotermes spa subteran termite on Wasian (Elmerrelia celebica L.) an Endemic Wood to North Sulawesi. International Journal of Science and Engineering Investigations. 2 (22), 8-16.

7. Orpin, C.G., Mathiesen, S.D., Greenwood, Y., \& Blix, A.S. (1985). Seasonal changes in the ruminal microflora of the high-arctic Svalbard reindeer (Rangifer tarandus platyrhynchus). Applied and Environmental Microbiology. 50 (1), 144-151.

8. Sundset, M.A., Edwards, J.E., Cheng, Y.F., Senosiain, R.S., Fraile, M.N., Northwood, K.S., Praesteng, K.E., Glad, T., Mathiesen S.D., \& Wright, A.D. (2009). Rumen microbial diversity in Svalbard reindeer, with particular emphasis on methanogenic archaea. FEMS Microbiol Ecol. 70 (3), 553-562. DOI: 10.1111/j.1574-6941.2009.00750.x.

9. Tarakanov, B.V. (2006). Methods for studying the microflora of the digestive tract of farm animals and poultry. M.: Scientific world.

10. Tepper, E.Z., Shilnikova, V.K., \& Pereverzeva, G.I. (1993). Workshop on microbiology. M.: Kolos.

11. Tolpysheva, T.Y. (2014). Mycotoxins, usnic acid, and their distribution in the lichens belonging to the genera cetraria, flavocetraria, cladonia. Vestnik of Moscow university. Seriya 16. Biologiya. 3, 37-41. 